\title{
LavTIME - A Brand-New Treatment Method of Lasting Wounds - A Multi-Centre Randomized Double-Blind Study on Effectiveness of Polyhexanide and Betaine in Ulcers' Healing with Venous Origin
}

\author{
Z. Rybak ${ }^{1}$, G Krasowski2,4, R. Wajda ${ }^{2}$ and P. Ciesielczyk ${ }^{3}$ \\ ${ }^{1}$ Department of Experimental Surgery and \\ Biomaterials Research Wrocław Medical University \\ ${ }^{2}$ County Hospital, Krapkowice \\ ${ }^{3}$ Ars Medica Wroctaw \\ ${ }^{4}$ University of Technology, Opole \\ Poland
}

\section{Introduction}

In ulcers' healing the organic contaminations causes a problem that are not scrupulously removed by patients or medical personnel, particularly, where approximately $90 \%$ patients suffering from the disease have been cured in an open system care. Secondly, up to the latest days there was no appropriate medicine effectively supporting wound's cleaning. Necrotic organic substances remaining in the wound do activate a holder's immunological system and promote bacteria, fungi, and virus increments, in which environment reactive oxygen species are created. These very aggressive substances destroy healthy tissues and favour accumulating significantly extensive amount of granulocytes which, in turn, affect microobstructions and micro-clots in the wound's edge area. The mentioned circumstances suspend the healing or even preclude this process. Another issue is, that majority of patients do not rinse up the whole wound surface while the edges only or they do not change bandages sufficiently often. A commonly used salt to rinse the wound is a physiological salt or Ringer's liquid. However, these are the liquids which do not contain a conservation mean. Therefore, outstaying usually in an open way for many days, or more often in a room temperature, the solutions can be secondarily contaminated. What is more, patients often use a tap water which is also bacterially contaminated. Having in mind a nature of the wound's protein components, which are strongly associated with a substratum via fibrins, it is not indifferent what the wound is rinse up with $(1,2,3,4)$.

In the study, the Authors present a new tactics against lasting wounds. It relies on supplementing the TIME procedure by the Lav acronym which means lavage (washing, cleaning) in the first instance, before wound treatment. Moreover, an effectiveness of wound cleaning from the organic elements including bacteria using a physiological salt $(\mathrm{NaCl})$ and Prontosan (polyhexanide+betaine) has been reported $(5,6)$. 


\section{Material and method}

In the study have been enrolled 60 patients (19 males and 41 females, 47-83 of age with 58.5 average). Retired persons (52 patients) were predominant in the group, widowers (43), alone (39) and inhabitants of a >100 thou. population city (38). All the patients have been suffering from thrombosis for 2-15 years. In the color duplex Doppler's test in all the patients signs of post thrombotic syndrome with damage of venous valves on different levels of the extremity has been diagnosed. A valve damage in femoral vein was predominant in 49 patients (formerly treated but unsuccessfully).

\begin{tabular}{|l|l|l|l|}
\hline & Male & Female & Total \\
\hline Gender & 19 & 41 & 60 \\
\hline Retired & 14 & 38 & 52 \\
\hline Widower & 9 & 34 & 43 \\
\hline Alone & 7 & 32 & 39 \\
\hline $\begin{array}{l}\text { Citizen of }>\text { 100 thou. } \\
\text { population city }\end{array}$ & 12 & 26 & 38 \\
\hline $\begin{array}{l}\text { Kind of profession } \\
\text { a/ physical worker, } \\
\text { farmer } \\
\text { b/ office worker } \\
\text { c/ student }\end{array}$ & 11 & 27 & 38 \\
\hline Age & 6 & 14 & 20 \\
\hline Median & 2 & 0 & 2 \\
\hline Range & $56+/-14$ & $63+/-14$ & \\
\hline BMI & 55 & 62 & \\
\hline Median & $(20-87)$ & $(24-88)$ & \\
\hline Range & $27,3+/-5,3$ & $28,7+/-5,1$ & \\
\hline
\end{tabular}

Table 1. The patient demographics

In the study 30 patients were taken into account with 44 ulcers' histories (158 visit records). From the preliminary set of 60 patients, those were excluded who appeared once or who did not restrict the regimes of the treatment procedure. After decoding the bottles' containments and appropriate patients' assigning to the groups, it was established that 17 patients were treated by Prontosan, whereas 13 by the $0.9 \% \mathrm{NaCl}$ solution, respectively.

Drop out patients are presented in table 2.

\begin{tabular}{|l|l|l|l|}
\hline & Prontosan group & $0.9 \% \mathrm{NaCl}$ group & Total \\
\hline Adverse events & 3 & 2 & 5 \\
\hline Major protocol violation & 2 & 4 & 6 \\
\hline Patient wished to leave study & 3 & 5 & 8 \\
\hline Patient not compliant & 4 & 3 & 7 \\
\hline Significant concomitant illness & 1 & 3 & 4 \\
\hline Treatment failure & 0 & 0 & 0 \\
\hline Total & 13 & 17 & 30 \\
\hline
\end{tabular}

Table 2. 


\subsection{Study design}

This study was an open, multicenter, prospective, randomized, double blind, parallel group study on efficacy of Prontosan solution in treatment of venous leg ulcers.

The study was performed in 3 centers and was included a total number of 60 patients. After dropped out 30 patients because of different reasons remaining patients were as follow : 17 patients for Prontosan and 13 for $0.9 \% \mathrm{NaCl}$ subgroup. Treated venous leg ulcers were classified according to ABI / Ankle-Brachial Index/. The venous leg ulcers were recognized when $A B I$ was higher than or equal to 0,9 and no lymphatic disorders revealed.

All study participants had been treated during 12 weeks or until complete healing is achieved (whichever occurs first).

\subsection{Study population}

The study population consists of individuals above 18 years of age, in which venous leg ulcers have been identified of the size limited by the size of applied wound dressing and $A B I \geq 0.9$.

Exclusion criteria were as follows:

a. hypersensitivity to any of Prontosan ${ }^{\circledR}$ components or to any of wound dressing components,

b. active osteomyelitis in the area of the treated ulcer,

c. active rheumatoidal or collagen disease of blood vessels treated with corticosteroids,

d. neoplastic disease

e. serum proteins $<4 \mathrm{~g} / \mathrm{dl}$

f. anemia: $<10 \mathrm{~g}$ haemoglobin per $\mathrm{dl}$

g. exclusion of phlebotropic, vasorelaxing and reological medicines for the study period

h. diabetic foot

i. lack of compliance of the patient

j. intolerance to compression therapy

\subsection{Route of administration}

External application.

\subsection{Dosage regimen}

Either Prontosan ${ }^{\circledR}$ or saline solution (depending on the study group) had been applied at every change of the wound dressing. Frequency of dressing change: every day.

\section{Application}

1. first, Prontosan/saline solution was used for cleansing of the wound bed; this will be done using sterile gauze \& sterile gauze compress soaked in the solution an used to cover the wound for $15 \mathrm{~min}$, then removed from the wound bed

2. next, the polyurethane wound dressing was activated with given solution and used to cover the wound

3. finally, medical compression stockings was used to fasten the wound dressing to the patient's leg. 
Prontosan or $0.9 \% \mathrm{NaCl}$ solution were used to soak and gently remove the wound dressing at the time of each dressing change procedure.

For each patient 10 bottles $350 \mathrm{ml}$ of Prontosan or $0.9 \% \mathrm{NaCl}$ saline solution were available and used as necessary according to applied randomization scheme.

\subsection{Efficacy criteria}

Primary efficacy criteria:

1. incidence of infection during treatment period

2. rate of healing of the ulcer in $\mathrm{cm}^{2} /$ week

Secondary efficacy criteria:

1. complete healing of the ulcer - ulcer is defined as completely healed if there is stable wound epithelialization

2. improved state of the ulcer - ulcer is defined as improved if there is decrease in its surface of at least $25 \%$ in comparison to the initial findings

3. lack of improvement of the ulcer - defined as the ulcer that do not belong to any of the above listed categories

Tertiary efficacy criteria:

1. incidence of pain during dressing change, comfort for the patient - subjective pain scale used during the course of study - before, during and after each dressing change (CIVIQ questionnaire)

2. incidence of side effects

3. change of clinical symptoms of the ulcer (granulation, epithelialization; computer-aided analysis of digital pictures of the wound).

\subsection{Methods of evaluation of the efficacy of treatment include:}

- $\quad$ planimetry of the ulcer, software-aided surface evaluation,

- $\quad$ assessment of clinical status of the ulcer (computer-aided analysis of pictures of wound surface)

- $\quad$ assessment of changes in microbial load in the ulcer in first, second \& last visit of the study

- photographic documentation of the treatment (done in a standardized way to allow for further computer-aided analysis)

- laboratory tests: full blood count, total proteins

\subsection{Safety evaluation}

Assessment of differences between measured general health parameters (as listed under laboratory tests) as well as incidence of adverse reactions before and after therapeutical process.

Following the study qualification during the initial visit (D-0), for bacteria culture inoculation, swabs from the wounds were taken and bottles with unknown liquid together with the treatment prescription among the patients were distributed. During the control visits before bandaging a digital photographical documentation of healing was conducted. 
The treatment procedure consisted with:

Every day applying wet gauze with the liquid from the bottle. The dressing was on the wound during fifteen minutes than polyurethan wound dressing ( Allevyn ) was put on. Such dressing was covered by two knee stockings. First was a thrombo profilactic and the second one was Sigvaris 503 class compression. Day by day patient change the dressings according to above mentioned method. To make easier for the patients each one get diary with detail prescription how to use getting materials for the treatment.

The visits' D-13 and D-31, D-58 consisted with: check the wound healing process, make a digital photography, take the culture from the wound bed, put the new dressing on, take used bottles off and give new bottles with the medicament.

The last visit was D-85. During this visit physician estimated the healing process, advers events and ask patients about their satisfaction with the treatment.

\section{Statistical analysis}

In the statistical analysis, hierarchical (multi-level) modelling has been performed that allows variance in outcome variable (wound surface) to be analysed at multiple hierarchical levels (i.e. time of treatment, treatment groups and their interaction) [Raudenbush S., Bryk A. (2001). Hierarchical Linear Models: Applications and Data Analysis Methods (2nd ed.). Sage Publications, Thousand Oaks CA]. A mixed effects' model has been applied in the study.

A statistical difference between means of the speed of ulcers' healing in Prontosan and $\mathrm{NaCl}$ patients has been estimated with the use of Welch's $t$-test that is an adaptation of Student's $t$-test intended for use with two samples having possibly unequal variance [Welch B. (1947). The generalization of "student's" problem when several different population variances are involved. Biometrika 34: 28-35] for details.

A so-called $k$-means algorithm which classifies a given data set (speed of ulcers' healing) through a certain number of clusters (two time bands) [MacQueen J. (1967). Some Methods for classification and Analysis of Multivariate Observations. Proceedings of 5-th Berkeley Symposium on Mathematical Statistics and Probability. Berkeley, University of California Press 1:281-297].

A statistical difference in infection numbers between the selected Prontosan and $\mathrm{NaCl}$ patients' visits has been estimated through the Mann-Whitney U-test [Mann H., Whitney D. (1947). On a test of whether one of two random variables is stochastically larger than the other. Annals of Mathematical Statistics 18: 50-60], which is a non-parametric test and assesses whether two independent samples of observations (infection numbers in treatment groups) come from the same distribution.

The statistical computation has been conducted in $\mathrm{R}$ platform [The $\mathrm{R}$ Foundation for Statistical Computing (2008). R version 2.8.1 (2008-12-22)].

The planimetrical estimation of ulcers was carried out based on digital pictures of wounds with the use of the MapInfo 6.5 geographical software. 


\section{Results}

In the group of patients underwent study were 11 smokers but only two smokers belongs to the group of assessed patients, one in group of Prontosan and one in $0.9 \% \mathrm{NaCl}$ group.

The ulcer location was predominantly in ankle region (49), above ankle (11). Status of the wound before and following treatment are presented in table 3.

\begin{tabular}{|l|l|l|l|l|}
\hline Status of the wound & $\begin{array}{l}\text { Before } \\
\text { treatment } \\
\text { Prontosan }\end{array}$ & $\begin{array}{l}\text { Before } \\
\text { treatment } \\
0.9 \% \mathrm{NaCl}\end{array}$ & $\begin{array}{l}\text { After treatment } \\
\text { Prontosan }\end{array}$ & $\begin{array}{l}\text { After treatment } \\
0.9 \% \mathrm{NaCl}\end{array}$ \\
\hline necrosis & 7 & 6 & 0 & 1 \\
\hline Fibrinogen coating & 17 & 13 & 0 & 2 \\
\hline Infection & 9 & 6 & 2 & 5 \\
\hline Visible tendoms & 5 & 3 & 2 & 2 \\
\hline Fistulas & 0 & 0 & 0 & 0 \\
\hline Granulation faze & & & 17 & 9 \\
\hline Epithelialization faze & 0 & 0 & 17 & 3 \\
\hline
\end{tabular}

Table 3.

Total healing rate in the estimated groups is presented in table 4

\begin{tabular}{|l|l|l|}
\hline & Prontosan $\mathrm{n}=17$ & $0.9 \% \mathrm{NaCl} \mathrm{n}=13$ \\
\hline $\begin{array}{l}\text { Total healing of ulcer within } \\
90 \text { days }\end{array}$ & 16 & 6 \\
\hline $85 \%$ of ulcer healing & 1 & 3 \\
\hline $50 \%$ of ulcer healing & 0 & 3 \\
\hline $30 \%$ of ulcer healing & 0 & 1 \\
\hline $\begin{array}{l}\text { Lack of improvement of the } \\
\text { ulcer }\end{array}$ & 0 & 0 \\
\hline
\end{tabular}

Table 4.

All blood and urine tests were in of normal range before and following study procedure.

Only in three patients of Prontosan group appeared adverse events listed in table 5.

\begin{tabular}{|l|l|l|}
\hline & Prontosan $\mathrm{n}=17$ & $0.9 \% \mathrm{NaCl} \mathrm{n}=13$ \\
\hline Serious adverse events & 0 & 0 \\
\hline Not serious adverse events & & \\
\hline Headache & 0 & 1 \\
\hline Excitation/sleepless & 0 & 0 \\
\hline Stabbing pain of the heart & 0 & 0 \\
\hline Nausea & 0 & 0 \\
\hline Itching & 2 & 3 \\
\hline Eruption of the skin & 1 & 3 \\
\hline Oedema foots and legs & 0 & 2 \\
\hline
\end{tabular}

Table 5. 
In the study 30 patients (17 Prontosan and $130.9 \% \mathrm{NaCl}$ ) were taken into account with 44 ulceration episodes (mean age $=71.9+/-10.7$ ). All together in 2008 and 2009, 158 visits were documented in the form below:

$\begin{array}{lllll}\text { Episode } & \text { Treatment Time since 1st visit [days] } & \text { Time between visits [days] } & \text { Surface [mm²] } \\ 1 & \text { Prontosan } & 0 & 0 & 3006,7 \\ 1 & \text { Prontosan } 42 & 42 & 2057 \\ 1 & \text { Prontosan } 75 & 33 & 1240,9 \\ 1 & \text { Prontosan } 151 & 76 & 183,6 \\ 1 & \text { Prontosan } 186 & 35 & 33,4 \\ 1 & \text { Prontosan } & 224 & 38 & 64,2 \\ 2 & \mathrm{NaCl} & 0 & 0 & 110,6 \\ 2 & \mathrm{NaCl} & 14 & 14 & 178,6 \\ 2 & \mathrm{NaCl} & 17 & 3 & 176 \\ 2 & \mathrm{NaCl} & 57 & 40 & 45,9 \\ 2 & \mathrm{NaCl} & 71 & 14 & 30,1 \\ 3 & \mathrm{NaCl} & 0 & 0 & 286,2 \\ 3 & \mathrm{NaCl} & 17 & 17 & 198,5 \\ 3 & \mathrm{NaCl} & 33 & 16 & 133,3 \\ 4 & \mathrm{NaCl} & 0 & 0 & 476,2 \\ 4 & \mathrm{NaCl} & 14 & 14 & 510 \\ 4 & \mathrm{NaCl} & 70 & 56 & 467 \\ 4 & \mathrm{NaCl} & 91 & 21 & 419,8 \\ * * * * * & * * * * * * * & * * * * * * * * * * * * * * * & * * * * * * * * * * * * * * * & * * * * * * * * *\end{array}$

\section{Ulcers' Surface in Patients}

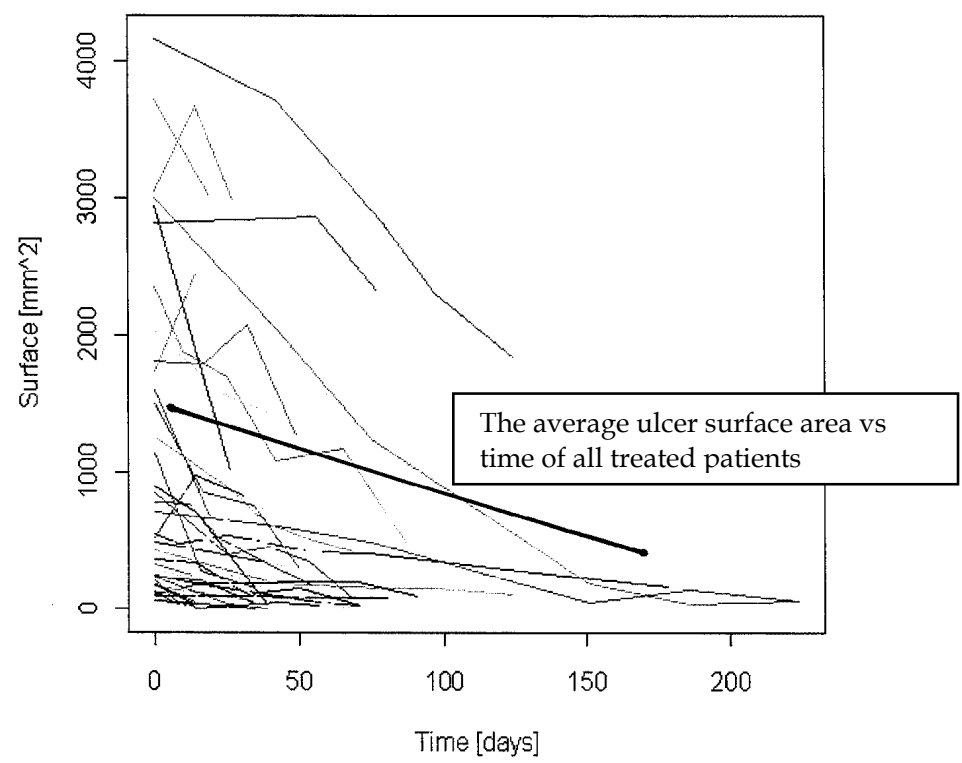

Fig. 1. 


\section{Ulcers' Surface in Patients by Groups}

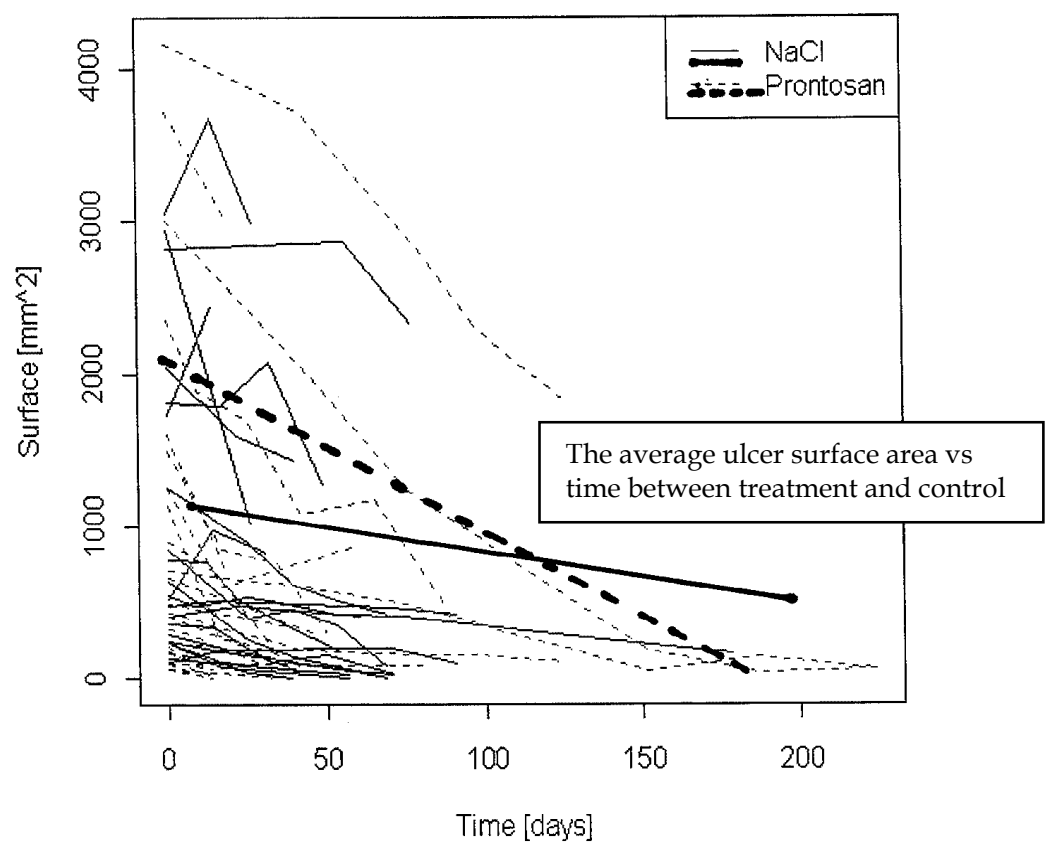

Fig. 2.

The regression estimates of the assumed hierarchical model are reported in Table 6.

$\begin{array}{llll}\text { Parameter } & \text { Value } & \text { Std. Error } & p \text {-value } \\ \text { intercept } & 1012,796 & 178,385 & <0,0001 \\ \text { time } & -4,053 & 1,168 & 0,0007 \\ \text { groupProntosan } & -86,154 & 194,633 & 0,6589 \\ \text { time:groupProntosan } & -5,004 & 1,479 & 0,0010\end{array}$

Table 6. Hierarchical Modelling Analysis

- A statistically significant reduction of the surface of ulcers in Prontosan and in $\mathrm{NaCl}$ patiens was observed approximately $4 \mathrm{~mm}^{2}$ per day (time);

Prontosan patients represented a larger reduction of the wound surface during treatment compared to $\mathrm{NaCl}$ patients $\left(86 \mathrm{~mm}^{2}\right.$ in average) , however, the difference was not statistically significant (groupProntosan);

- A statistically significant difference in healing effect in time between the treatment groups was observed and for each therapy increment of one day, the reduction of 5 $\mathrm{mm}^{2}$ was larger approximately in Prontosan patients compared to $\mathrm{NaCl}$ group (time:groupProntosan).

The graphical model of the reduction of ulcers in treatment groups is presented in Figure 3. 


\section{Ulcers' Surface Reduction Model}

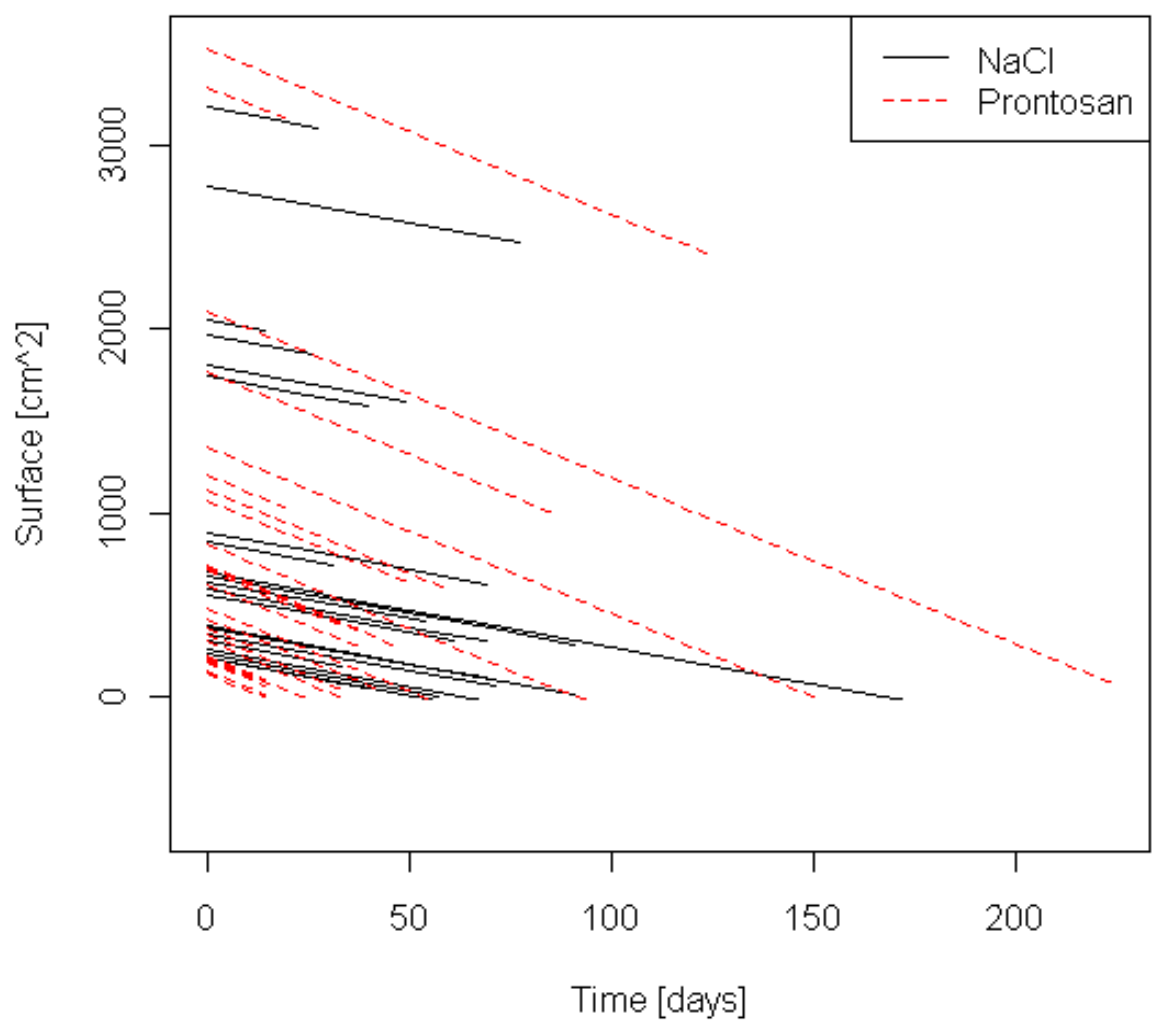

Fig. 3.

The regression model estimates indicate that a particular $1000 \mathrm{~mm}^{2}$ ulcer wound should be approximately healed after 110.4 days of Prontosan therapy whereas 246.8 days with the $\mathrm{NaCl}$ treatment.

The estimates of the statistical difference between means of the speed of ulcers' healing in Prontosan and in $\mathrm{NaCl}$ patients are presented below

$\begin{array}{cccc}\text { Treatment } & \text { Mean } & \text { Std. Dev. } & p \text {-value } \\ \text { Prontosan } & 13,320 & 14,763 & 0,01465 \\ \mathrm{NaCl} & 5,641 & 18,124 & \end{array}$

Table 7. Ulcers' Healing Speed $t$-test $\left(\mathrm{mm}^{2}\right)$

The $t$-test estimates provide evidence of the over twice as high ulcer reduction in Prontosan treatment patients compared to $\mathrm{NaCl}$ group. The average healing in Prontosan patients exceeded $13 \mathrm{~mm}^{2}$ per day whereas in $\mathrm{NaCl}$ patients it was much below $6 \mathrm{~mm}^{2}$ daily. The difference in means is statistically significant. 


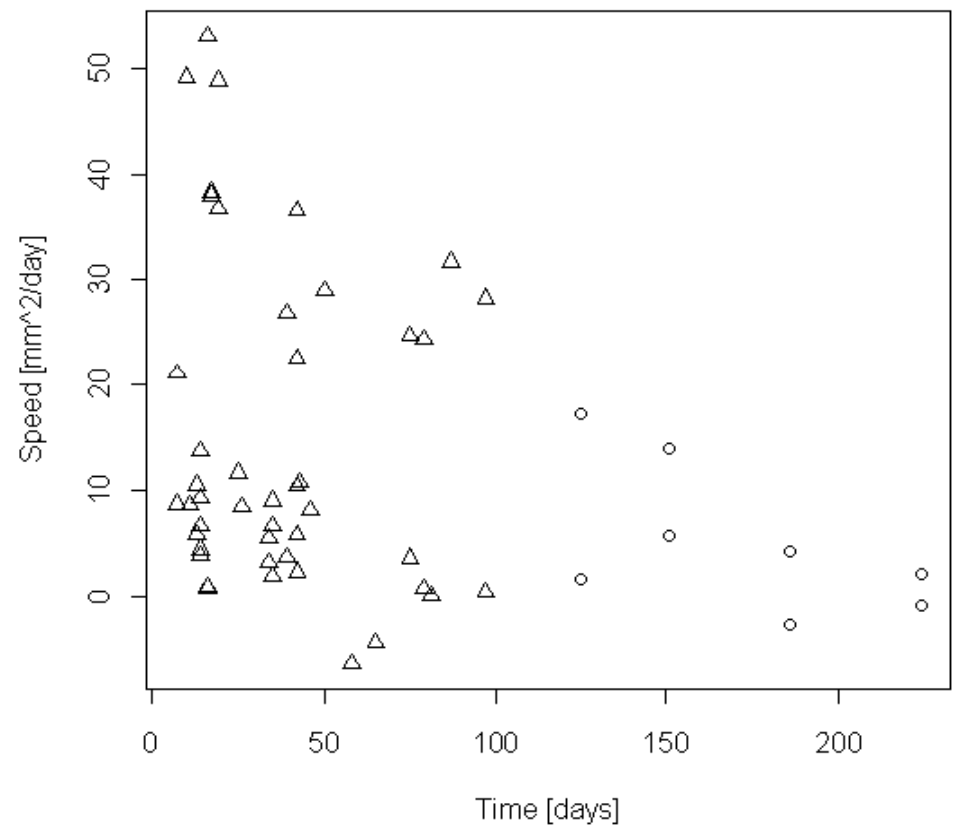

Fig. 4. Time-Speed Clusters of Ulcers' Healing in: Prontosan Patients

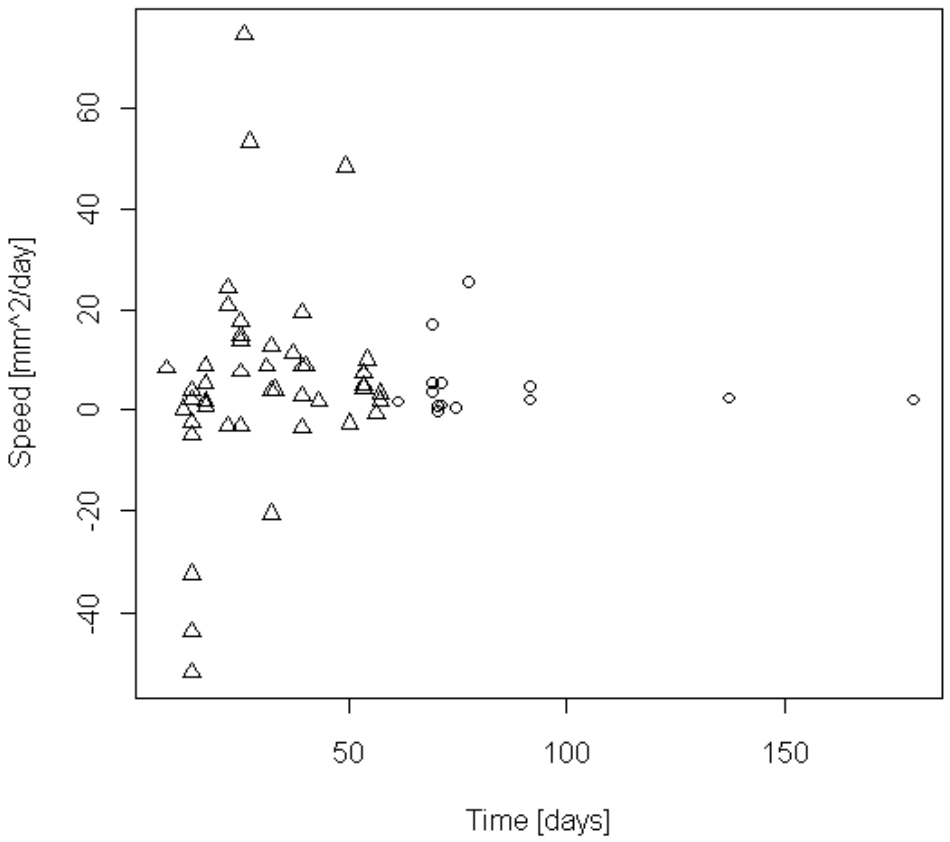

Fig. 5. Time-Speed Clusters of Ulcers' Healing in: $\mathrm{NaCl}$ patients 


$\begin{array}{llll}\text { Treatment } & \text { Means } & & \\ & \text { Cluster 1 } & \text { Cluster 2 } & p \text {-value } \\ \text { Prontosan } & 14,770 & 5,164 & 0,00931 \\ \mathrm{NaCl} & 5,730 & 5,347 & 0,9152\end{array}$

Table 8 . The $t$-test analysis for the time-speed clusters in Prontosan and $\mathrm{NaCl}$ patients are given

The outcomes testify that there is a significant difference in means of healing speed in Prontosan patients between the estimated clusters. The obtained time band can be established around the 100 days since the beginning of Prontosan treatment and the average speed of ulcer healing reaches nearly $15 \mathrm{~mm}^{2}$ per day up to this time border. After this time the speed decreases significantly to $5 \mathrm{~mm}^{2} /$ day. The healing speed in $\mathrm{NaCl}$ patients does not vary with time and in both clusters it is slightly above $5 \mathrm{~mm}^{2}$ per day of treatment.

$\begin{array}{cccccc}\text { Treatment } & \text { No. of Obs. } & \text { Rank Sum } & U \text { statistic } & Z \text { statistic } & p \text {-level } \\ \text { Prontosan } & 27 & 509,5 & 131,5 & -3,9054 & 9,43 \mathrm{E}-05\end{array}$

$\mathrm{NaCl} \quad 26 \quad 921,5$

Table 9. The $U$-test results for the infection numbers between the selected Prontosan and $\mathrm{NaCl}$ patients' visits are reported U-Test Infection Numbers Analysis

The results provide evidence of significantly lower infection numbers in Prontosan patients' ulcers in comparison to the $\mathrm{NaCl}$ group (nearly twice as low).

\section{Discussion}

In the study 30 patients were taken into account with 44 ulcers' histories (158 visit records). From the preliminary set of 60 patients, those were excluded who appeared once or who did not restrict the regimes of the treatment procedure. After decoding the bottles' containments and appropriate patients' assigning to the groups, it was established that 17 patients were treated by Prontosan, whereas 13 by the $\mathrm{NaCl}$ solution, respectively.

The obtained outcomes provide evidence nearly three times as a higher healing speed in those patients who were treated by Prontosan in comparison to the $\mathrm{NaCl}$ group. The cleaning from bacteria tribes was as twice as higher, respectively. In both the analyses the results were statistically significant.

The importance of lavasepsis for the treatment of chronic wounds results from a fundamental, commonly understood and accepted standard, which for wound management field translates as follows: "first wound hygiene, then wound tratment (7)." This principle goes hand in hand with the generally accepted rule of limiting the use of drugs to an essential minimum and giving prophylaxis priority in medicine. What is then the real impact of lavasepsis on the individual elements of the TIME framework?

The effect of lavasepsis on Tissue management is many-sided. It softens and separates necroses from healthy tissue, which facilitates their identification and elimination. Furthermore, lavasepsis removes crust, scabs and exudate residues, as well as fibrin coatings from the wound surface $(8,9)$. Finally, everyday wound lavasepsis secures effective biofilm removal (10). Wound lavasepsis cannot replace surgical interventions or sharp 
debridement, but it can considerably help in assessment of the wound and in effective employment of the required procedure.

In the area of Inflammation and infection control, it is worth emphasising the significance of the aforementioned cleansing properties, namely the removal of wound coatings and biofilm from the wound surface. The use of antiseptics and antibiotics for a wound that is either contaminated or coated with a biofilm is inadequate. It can cause the therapy to be ineffective and increases the likelihood of the development of drug-resistance $(12,14)$. Wound cleansing or hygiene lowers the microbial load and significantly lowers the risk of complications, including infections. The microcirculation, oxygen and nutrient availability, as well as the effectiveness of patient's immune system are improving. Lavasepsis cannot replace antisepsis, but secures optimal conditions for the use of local and systemic antiinfectives. In this way, it minimizes and streamlines their application.

Maintaining an adequate Moisture balance of the wound is an important element of the therapeutic process. Everyday wound lavasepsis helps to remove excessive exudate (also by reinforcing the habit of wound cleansing). It facilitates wound moistening in the case of dry wounds and raises the effectiveness of wound dressings. Lavasepsis is not meant to replace modern wound dressings, which are essential for maintaining a moist wound environment and absorbing excessive exudate. It can, however, prepare the wound bed in a way that ensures optimal therapeutic effect of their application.

Epithelial/edge advancement is an element of the TIME framework, for which lavasepsis is important because of the fact that the removal of wound coatings facilitates the reestablishment of cellular proliferation and angiogenesis. Lavasepsis also removes potential physical barriers to epithelial growth across the wound bed. Finally, optimal wound bed preparation is a prerequisite for effective use of advanced therapies, such as skin transplants and cellular growth factors (11).

Lavasepsis thus has a significant influence on all elements of the TIME framework, being a process of preparing the wound bed per se. Thanks to this, it allows one to achieve optimal results from any therapeutic procedures applied at specific stages of wound treatment.

The above outcomes point to the conclusion that a lack of effective wound cleaning from organic elements laying on the wound bed as well as from the remained bacteria (protected by the bacterial biofilm which is difficult to remove using physiological salts) result in significant elongation of the healing time. Prontosan dissolves and removes contaminations from the wound bed, destroys the bacterial biofilm and accelerates the healing of ulcers. Despite of a slightly higher price, the use of Prontosan may importantly reduce sufferance in patients likewise both the costs carried out by their own and the governmental subsidies, taking the time of the medical treatment in mind. Further economical simulation are required to estimate such the profits. Our results were confirmed by other investigators (12).

Lavasepsis is a new term created to describe and delineate a group of products that, according to the authors, brings in a new, desired quality to local treatment of chronic wounds (13). This new quality arises directly from the evolution of the WBP paradigm and TIME framework set earlier by EWMA experts (14). The TIME framework and EWMA recommendations are a good milestone not only for clinical practice, but also for manufacturers who are trying to adopt their product offering to the needs of contemporary medicine. The LAV-TIME concept presented in this paper, extends and supplements the 
TIME framework with the new and important element of lavasepsis $(15,16,17,18)$. Although at present there are few products on the market that can be described as "lavaseptics", the rapid development of this group of products is to be expected, and their availability on the medical market will grow. This would certainly be of benefit to the medical world, and most of all to the patients $(19,20)$.

\section{Conclusion}

1. A statistically significant difference in healing effect in time between the treatment groups was observed and for each therapy increment of one day, the reduction of 5 $\mathrm{mm}^{2}$ was larger approximately in Prontosan patients compared to $\mathrm{NaCl}$ group.

2. The results provide evidence of significantly lower infection numbers in Prontosan patients' ulcers in comparison to the $\mathrm{NaCl}$ group.

3. Prontosan appeared as a very good tolerated product for patients without any serious adverse effects. Only three out of seventeen patients have a temporary local problems with Itching ( two patients) and eruption of the skin (one patient).

4. 16 patients out of 17 in the Prontosan group were totally healed within 90 days of treatment and only 6 out of 13 were totally healed in $\mathrm{NaCl}$ group at the same time.

\section{References}

[1] Kramer A, "Antiseptika und Händedesinfektionsmittel“. W: Korting HC, Sterry W (Hrsg) Therapeutische Verfahren in der Dermatologie. 2001, Blackwell Wissenschaft Berlin, 273-294.

[2] Kramer A, Adrian V, Rudolph P, Wurster S, Lippert H, “Explantationstest mit Haut und Peritoneum der neonatalen Ratte als Voraussagetest zur Verträglichkeit lokaler Antiinfektiva für Wunden und Körperhohlen“. 1988, Chirurg 69, 8:840-845.

[3] Kallenberger A, Kallenberger C, Willenegger H, „Experimentelle Untersuchungen zur Gewebeverträglichkeit von Antiseptika“. 1991, Hyg Med 16, 10:383-395.

[4] Sellmer W, „Lokaltherapeutika, speziell Antiseptika, in der Behandlung chronischer Wunden - eine aktuelle Bewertung“. 2001, Med Praxis 2: 20-30.

[5] Schmit-Neuerburg KP, Bettag Ch, Schlickewei W, Fabry W, Hanke J, Renzing-Kohler K, Hirche H, Kock H-J, "Wirksamkeit eines neuartigen Antisepticum in der Behandlung kontaminierter Weichteilwunden“. 2001, Chirurg 72: 61-71.

[6] Seipp H-M et al., „Wirksamkeit verschiedener Wundspuillösungen gegenuiber Biofilmen“. 2005, Zeitschrift für Wundheilung, 1, 160-164.

[7] European Wound Management Association (EWMA). Position Document: Wound Bed

[8] Preparation in Practice. London: MEP Ltd. 2004

Ciesielczyk P, Rybak Z, „Prawidłowe przygotowanie łozyska rany i profilaktyka

[9] antybakteryjna - droga do sukcesu w leczeniu ran. Zastosowanie Prontosanu i produktów PVP-jodowych". Streszczenia. II Kongres Naukowo-Szkoleniowy Polskiego Towarzystwa Leczenia Ran. 2007, Leczenie Ran 4(4): 140.

[10] Kramer A et al., "Consensus recommendation on wound antisepsis". 2004, Zeitschrift für Wundheilung 3.

[11] Werner HP, „Die mikrobizide Wirksamkeit ausgewählter Antiseptika“. 1992, Hyg Med 17, 2:51-59. 
[12] Kramer A, Adrian V, Rudolph P, Wurster S, Lippert H, “Explantationstest mit Haut und Peritoneum der neonatalen Ratte als Voraussagetest zur Verträglichkeit lokaler Antiinfektiva für Wunden und Körperhohlen“. 1988, Chirurg 69, 8:840-845.

[13] Kallenberger A, Kallenberger C, Willenegger H, „Experimentelle Untersuchungen zur Gewebeverträglichkeit von Antiseptika“. 1991, Hyg Med 16, 10:383-395.

[14] Sellmer W, „Lokaltherapeutika, speziell Antiseptika, in der Behandlung chronischer Wunden - eine aktuelle Bewertung“. 2001, Med Praxis 2: 20-30.

[15] Selvaggi G et al., "The role of iodine in antisepsis and wound management: a reappraisal". 2003, Acta chir. belg 103, 241-247.

[16] Seipp H-M and Stroh A, "Methicillin-resistant S. aureus (MRSA) - Significant reduction of incidence and rate in a maximum-care clinical centre (1994 to 1999)". 1999, Hyg Med 24 (6): 224-237.

[17] Ciesielczyk P., Michalski T., Rybak Z.: LA V-TIME. Ewolucja paradygmatu,2007, Zakazenia;6:104-108.

[18] Rybak Z.: Venous leg ulcers, 2008, Sepsis;1(2):95-98.

[19] Rybak Z., Cisielczyk P.: Lavasepsis as a helpful method in wound treatment, 2008, Dermat. Estet;10(2):104-106.

[20] Kramer A, "Antiseptika und Handedesinfektionsmittel“. W: Korting HC, Sterry W (Hrsg) Therapeutische Verfahren in der Dermatologie. 2001, Blackwell Wissenschaft Berlin, 273-294. 


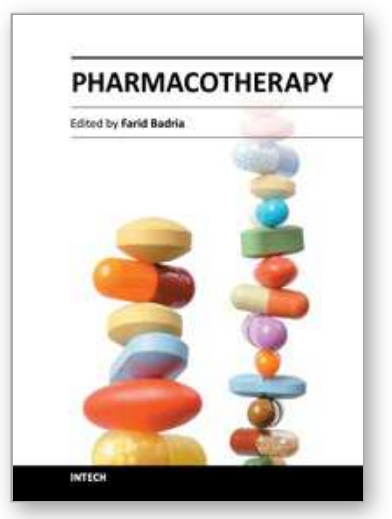

\author{
Pharmacotherapy \\ Edited by Dr. Farid Badria
}

ISBN 978-953-51-0532-9

Hard cover, 194 pages

Publisher InTech

Published online 29, June, 2012

Published in print edition June, 2012

The intent of this book is to provide an overview of current conceptualizations of Pharmacotherapy. The book focuses on three major areas; diagnosis, treatment, and prevention for a wide array of diseases; Cognitive and Psychological disorders (Schizophrenia and Nicotine addiction), Inflammatory disorders (New Chemical antiinflammatory and Immunotherapy), updated antihypertensive therapy and healing of ulcers with venous origin. A separate chapter is dedicated to the rationality of drug use in earthquake injuries. The last chapter deals with Imaging of potential therapeutic or diagnostic agents in animal models in the early stage of research. We hope this book is useful to a wide range of people, from students first learning about Pharmacotherapy, to advanced clinicians and researchers.

\title{
How to reference
}

In order to correctly reference this scholarly work, feel free to copy and paste the following:

Z. Rybak, G Krasowski, R. Wajda and P. Ciesielczyk (2012). LavTIME - A Brand-New Treatment Method of Lasting Wounds - A Multi-Centre Randomized Double-Blind Study on Effectiveness of Polyhexanide and Betaine in Ulcers' Healing with Venous Origin, Pharmacotherapy, Dr. Farid Badria (Ed.), ISBN: 978-953-510532-9, InTech, Available from: http://www.intechopen.com/books/pharmacotherapy/lavtime-a-brand-newtreatment-method-of-lasting-wounds-a-multi-centre-randomized-double-blind-st

\section{INTECH}

open science | open minds

\author{
InTech Europe \\ University Campus STeP Ri \\ Slavka Krautzeka 83/A \\ 51000 Rijeka, Croatia \\ Phone: +385 (51) 770447 \\ Fax: +385 (51) 686166 \\ www.intechopen.com
}

\author{
InTech China \\ Unit 405, Office Block, Hotel Equatorial Shanghai \\ No.65, Yan An Road (West), Shanghai, 200040, China \\ 中国上海市延安西路65号上海国际贵都大饭店办公楼405单元 \\ Phone: +86-21-62489820 \\ Fax: $+86-21-62489821$
}


(C) 2012 The Author(s). Licensee IntechOpen. This is an open access article distributed under the terms of the Creative Commons Attribution 3.0 License, which permits unrestricted use, distribution, and reproduction in any medium, provided the original work is properly cited. 